\title{
Globalization, tax erosion and the Internet
}

\author{
Citation for published version (APA):
}

Soete, L. L. G., \& ter Weel, B. J. (1998). Globalization, tax erosion and the Internet. MERIT, Maastricht Economic Research Institute on Innovation and Technology. MERIT Research Memoranda No. 022 https://doi.org/10.26481/umamer.1998022

Document status and date:

Published: 01/01/1998

DOI:

10.26481/umamer.1998022

Document Version:

Publisher's PDF, also known as Version of record

\section{Please check the document version of this publication:}

- A submitted manuscript is the version of the article upon submission and before peer-review. There can be important differences between the submitted version and the official published version of record.

People interested in the research are advised to contact the author for the final version of the publication, or visit the DOI to the publisher's website.

- The final author version and the galley proof are versions of the publication after peer review.

- The final published version features the final layout of the paper including the volume, issue and page numbers.

Link to publication

\footnotetext{
General rights rights.

- You may freely distribute the URL identifying the publication in the public portal. please follow below link for the End User Agreement:

www.umlib.nl/taverne-license

Take down policy

If you believe that this document breaches copyright please contact us at:

repository@maastrichtuniversity.nl

providing details and we will investigate your claim.
}

Copyright and moral rights for the publications made accessible in the public portal are retained by the authors and/or other copyright owners and it is a condition of accessing publications that users recognise and abide by the legal requirements associated with these

- Users may download and print one copy of any publication from the public portal for the purpose of private study or research.

- You may not further distribute the material or use it for any profit-making activity or commercial gain

If the publication is distributed under the terms of Article $25 \mathrm{fa}$ of the Dutch Copyright Act, indicated by the "Taverne" license above, 


\title{
Globalization, Tax Erosion and the Internet
}

\author{
Luc Soete $^{\mathrm{a}}$, Bas Ter Weel ${ }^{\mathrm{b}, *}$ \\ ${ }^{a}$ Department of Economics and \\ Maastricht Economic Research Institute on Innovation and Technology (MERIT), \\ Maastricht University, the Netherlands \\ ${ }^{b}$ Maastricht Economic Research Institute on Innovation and Technology (MERIT), \\ Maastricht University, the Netherlands
}

\begin{abstract}
Electronic commerce and globalization are, and will continue to be a challenge to tax collectors throughout the world. Globalization makes the cross-border movements in goods, capital and labour less transparent. Companies and individuals are therefore able to exploit tax differences between countries. The Internet eliminates borders between countries and furthermore makes businesses virtually invisible. At the consumer end, E-commerce makes the tracing of transactions and thus the taxing of goods and services sold and distributed via the Internet almost impossible. As a result, state and national governments' tax bases are, or are at risk of, being eroded.
\end{abstract}

* Corresponding author. MERIT, Maastricht University, P.O. Box 616, 6200 MD Maastricht, the Netherlands; Tel. ++31-43-3883873; E-mail: b.terweel@merit.unimaas.nl. 


\section{Introduction}

There is little doubt that, viewed in retrospect, the last ten years have been characterized by a period of historic, major structural transformation at a global level: the collapse of the former communist countries and their rapid opening up to market-led economic incentives; the shift in world market growth from the old North Atlantic OECD area to the Pacific basin area; the liberalisation of financial capital markets bringing about de facto the international mobility of capital; and finally and most importantly the dramatic reduction in the costs of information and communication processing, opening up an increasing number of sectors to international trade and giving at least the impression of a dramatic reduction in physical distances - the world as a global Information Society (IS).

This fast-paced global restructuring process, due to the increased importance of Information and Communication Technologies (ICTs), raises some fundamental challenges. At the national level, it has made policy makers much more aware of the increased international implications of their actions. Policy measures that might appear sustainable within a national context, might increasingly appear less so in an international context. While the impact of opening up to global restructuring might still be in its initial stages, it has rapidly brought to the forefront how degrees of freedom of national policy actions have been dramatically reduced in a wide variety of different fields. This does not only hold for macro-economic policy, but also for tax policy which was traditionally preserved at the national level.

The emerging IS, characterised by rapid change and high degrees of flexibility, will also require considerable adjustments by workers and firms. Growth in productivity, output and jobs must be built on a comprehensive foundation of technological progress and the development of human capital. Coherent policies must therefore create incentives for expanded investment in human capital, technology, innovation and information networks. Government policies must nurture this society and promote the adjustment towards the new era of the information society. To achieve this formidable goal, policies must create an environment in which each individual is provided with the skills and tools to participate in this new society. 
In the rapid evolution towards an IS the telecommunications market plays an important and decisive role by selling and creating the means to communicate, i.e. bandwidth. In this rapidly growing market bandwidth is usually sold on a timed basis - calls are billed based on the length of the call - while many leased lines and data lines are sold at a fixed price. However, while bandwidth capacity is increasing dramatically, it is highly doubtful that capacity growth can keep up with demand growth. The number of people who have acquired an Internet connection is doubling every year, while bandwidth is certainly not. ${ }^{1}$ In other words, key resources are and will remain scarce for the next twenty years. The most serious question will be how to allocate the scarce resources of the Internet.

The standard economic answer in this regard is to create markets and let prices allocate the scarce resources. However, the economic answer with respect to the Internet is not as straightforward as many economists might think. Currently, information is provided to the Internet user at a fixed price, regardless of the value of that information to particular users. If the information value is high to the consumer the same amount is paid as acquiring information for entertainment purposes. This point alludes to the difficulties and challenges associated with pricing information downloaded from the Internet. Several authors have addressed the problem of how to appropriately price the Internet - cf. Stahl (1997). At this stage, however, their models remain highly theoretical and their recommendations cannot be implemented either because of lack of knowledge and skills on the side of scientists or because of an unwillingness on the side of politicians. The real answer to the problem of Internet pricing might come from the Internet Service Providers (ISPs) and financial institutions, like banks.

In Europe, the High Level Expert Group on the Social Aspects of the Information Society (HLEG) has called for reflection and research on alternative taxation systems. One feasible approach they suggest is a bit tax. Such a tax may be a tool for governments to consider in an increasingly information-based world in which value is generated through systems and global networks, instead of through clearly identifiable material production and exchange, i.e. intangibles versus tangibles. Soete and Ter Weel (1998c) elaborate further on the idea suggesting

\footnotetext{
${ }^{1}$ Bandwidth has only increased from 56 kilobytes per second in the late eighties to 45 megabytes per second in 1996. In the near future bandwidth is expected to increase to 1 gigabit per second.
} 
research and an improved understanding of the taxation issues related to electronic commerce.

This paper discusses the case of taxing cyberspace and develops the case in favour of a tax on electronic commerce. We proceed in the following manner. In section 2 we discuss globalization and the difficulties regarding taxation in a general context. In section 3 we sketch a picture of consumer behaviour towards the IS in general and the Internet in particular by discussing the ex ante conditions consumers demand in order to enter the IS and or the Internet. First, we deal with buying decisions and show that Europeans have a comparative disadvantage compared to US consumers. Then, we investigate access issues to show the 'IS literacy' of the population and tax implications. Thereafter, in section 4, we explain the philosophy behind taxing electronic commerce. Then, we construct a business model to illustrate how the various players profit from the Internet. In assessing and collecting tax from transactions on the Internet this is an important exercise. This business model is useful in showing different monetary flows that occur when a consumer purchases a product from the Internet. Hence, by using this model we can identify the taxing possibilities; we propose three different ways to tax electronic commerce. We end with some concluding remarks. 


\section{Globalization and taxation}

Contemporary governments have increasing difficulties in collecting taxes and maintaining an adequate tax base. As the world becomes increasingly more integrated, and as capital and highskilled labour can move more easily and freely from high-tax countries to low-tax ones, a nation's tax regime has to adapt to some world standard because people and businesses can and will exploit differences in tax regimes. A nation can attract capital and high-skilled labour through tax exemptions. This can lead to in- and outflows of (human) capital. Countries with high tax rates such as Germany, Italy and Japan can suffer from such an outflow. For as capital and high-skilled labour flow out of these countries, the tax burden will be increasingly on lower skilled labour and (unmovable) physical property, which may eventually lead to an eroding tax base.

\section{Globalization of Money}

As in many other areas of structural change, there is an ongoing debate about the factual evidence surrounding globalization. Most of the readily available evidence tends to suggest that there has been little increase in globalization. International trade has increased rapidly over the last twenty years but not to such an extent as to explain in any way a structural break from the past. Similarly, foreign direct investment flows still only represent a small fraction of total investment in OECD countries. Clearly, such measures of international flows in trade and foreign direct investment reflect only one limited feature of globalization. Growth in the globalization of financial flows over the last two decades, for example, has been dramatic. ${ }^{2}$

The globalization of financial markets has been a heralded achievement. Innovations in technologies of computation and communications, new markets and institutions, and tides of deregulation have released a flood of domestic and international financial transactions - cf. Eichengreen, Tobin and Wyplosz (1995). Free marketeers hail the liberalisation of capital markets, brought about by the financial deregulation trend of the 1980s, as a major gain for the

\footnotetext{
${ }^{2}$ Cross-border transactions in bonds and equities have increased in OECD countries over the last 15 years from $10 \%$ of GDP in 1980 to between 150 and $250 \%$ of GDP in 1995. At the same time, the world-wide volume of foreign exchange trading has increased to a turnover of more than $\$ 1,200$ billion a day. (OECD, 1998)
} 
economy. Tobin (1978) has some doubts. According to him the functional efficiency of financial markets for the overall system can be enhanced by a universal transactions tax.

A Tobin tax has been advocated for at least four reasons. Frankel (1996) argues that a Tobin tax is useful as a tool for monetary reform to restore some form of monetary autonomy for national governments. Secondly, it can be used to reduce excess volatility in capital markets by shifting resources away from speculators to long-term investors. ${ }^{3}$ This argument forms the core of Tobin's idea. He starts from the observation that goods and labour move more sluggishly and slowly than money, in response to international price signals. Thirdly, market imperfections like asymmetric information, moral hazard in the banking system and multiple equilibria provide a rationale for market intervention. Finally, a Tobin tax is a market conform instrument to raise revenue for international projects and organizations. By imposing a tax that prevents excess capital flows and price fluctuations, the overall efficiency of the financial system can be increased -cf. Van Liederkerke (1997) for an overview.

A Tobin tax penalizes the short-term transactions more than long-term ones. Frankel (1996) demonstrate how a simple transaction tax has a progressive nature in terms of the duration of the investment. With a tax rate of $0.001 \%$ of the total amount invested, a dealer on the foreign exchange market with a one day horizon would need an annual return of $46.5 \%$ to make his investment attractive. An investment with a one year horizon would only incur the $0.001 \%$ cost, which is both in relative and absolute terms small. Given the fact that most trading takes place at a very short horizon, it is clear that even such a minimal tax would reduce a very large part of current trading activity and therefore volatility. Reductions in volatility seem te be necessary if we investigate the contemporary large fluctuations in financial markets.

\footnotetext{
${ }^{3}$ Eichengreen, Tobin and Wyplosz (1995) state that "[a] half percent tax translates into an annual rate of $4 \%$ on a three months' round trip into a foreign market, more for shorter round trips. It is this effect that creates room for differences in domestic interest rates, allowing national monetary policies to respond to domestic macroeconomic needs. The same tax would be a smaller deterrent to slower round trips. It would be a negligible consideration in long-term portfolio of direct investment in other economies. It would be too small, relative to ordinary commercial and transportation costs, to have much effect on commodity trade." (p. 164-165)
} 


\section{Globalization of Information and Communication}

Historically, the goods individuals consumed were physical and therefore the production, distribution and consumption of these goods were easily taxable. The inputs required for production could be easily measured, the value added generated through the whole industrial and distribution process easily traced and the final consumption easily located. Physical goods were produced at a manufacturing plant, shipped off to wholesalers and boxed on retailers shelves, with the final consumer walking away with a paid for product. Services have also been relatively easy to trace simply because they were difficult to transfer; consumers were forced to consume local services. In both cases the retailer, where appropriate, simply acted as the tax collector and remitted the VAT or sales tax to the government. The forces of globalization in combination with electronic commerce seem to be changing all this.

Intangible goods sold via the Internet, are typical information goods: the marginal cost of providing an extra unit is close to zero. If the price of an intangible good is also zero then of course there will be little opportunity to tax such a good. In addition, since no additional inputs are required, tax authorities can no longer cross-check a firm's units of inputs with its claimed units of output.

At first site, the development of electronic cash as opposed to credit card systems is likely to facilitate both electronic commerce and tax evasion since payment no longer leaves a paper trail and is, as in the case of real money, anonymous and untraceable. Today tax inspectors can check reported income and spending against bank and credit card statements. At present, ninety percent of all financial transactions linked to consumption take place using cash, checks and credit cards. These systems involve intermediaries such as banks, credit card companies or other financial institutions that leave an audit trail of payment - cf. Ganguly (1997). At the same time, Internet also reduces the role of intermediaries because a consumer can linea recta contact the producer of the good he wants to purchase. Finally, it becomes increasingly easy for the average citizen to access offshore financial centres on the Internet. Internet banking will offer simple access, low transactions costs, a certain amount of anonymity and immediate tradeability of funds.

The problem with taxing information communication services lies within the fact that the 
taxation rules were developed some twenty years ago. A wide variety of information-technologyrelated goods and services were developed since. The tax rules are based on a clear distinction between information transmission and information provision, or between broadcasting and entertainment. The rapid convergence between these different underlying technologies raise also questions with respect to the most appropriate tax regime.

At the centre of this process, one finds a cluster of new ICTs and the ability they provide to dramatically reduce communication and information handling and processing costs. ${ }^{4}$ In some areas, where this process has been accompanied by an institutional liberalisation and deregulation process, this globalization process has been most rapid and is nearly complete: financial capital has in essence become an internationally mobile production factor. In traditional manufacturing production, the decline in communication and information costs has further increased the international transparency of markets, reinforcing the scope for international location. In areas such as services, new ICTs are often for the first time allowing cheap global access to low cost labour locations thus facilitating the relocation of various routine service functions and activities. Firms and organisations have come to discover the benefits of international differences in labour costs in areas hitherto limited in their international tradeability - cf. Freeman and Soete (1994).

Resolving such issues will undoubtedly require cooperation amongst the major world economies. However, taxation concerns and responses within different economies reflects different tax regimes and philosophies. There is, particularly in the US, concern about overtaxing such new services possibly because of the continuous search at lower levels of jurisdiction for new sources of local government income. Many EU-countries are concerned about three other issues: international competitiveness, diffusion of electronic communication and the erosion of national tax revenues. Particularly, the diffusion of electronic communication and the access to electronic networks requires considerable action.

${ }^{4}$ While it might be something of a misnomer to talk about global access in a world in which half the population has no direct access to public telephony, the trend towards worldwide access is intrinsically linked with the ability of ICTs to codify information and knowledge over both distance and time. 


\section{How to access the IS}

As noted above, electronic commerce forms part of a broader process of social change, characterised by the globalization of markets, the shift towards an economy based on knowledge and information, and the growing prominence of all forms of technology in everyday life. These major societal transformations are now under way and will presumably continue far into the next century. As both a product and feasible part of such transformations, electronic commerce is being shaped by a changing society. Societal factors will merit attention from a public policy standpoint to establish the social conditions that allow electronic commerce to reach its full economic potential and to ensure that the fruits can be reaped by society as a whole. The most important element is access and its determinants and constraints. Access to new ICTs is regarded to be directly linked to income - cf. OECD (1998). Hence the main argument opposing taxing the Internet in particular and the IS in general is the (further) creation of a two-tier society. ${ }^{5}$

In order to see whether this argument is valid Ter Weel (1997, pp. 4-7) looks at the buying decisions of individuals with regard to a new product and investigates the number of Internet users and their behaviour by presenting figures on the number of users and the number of hosts. He found that only a percentage of less than 10 of the European Union (EU) population is 'Internet literate', while the income of far more than $50 \%$ of the EU households are able to afford an Internet connection. The determining factors to access new products in general and the

\footnotetext{
${ }^{5}$ Other arguments opposing taxing electronic commerce in general and taxing bits in particular are: (1) A transmission tax is in no way related to the economic value of the good. A video sent to a friend, with no commercial value but containing a large number of 'bits' would incur a much higher tax bill than a commercial database made up of fewer bits. The video has no commercial value, if sent via normal mail the video would hardly be taxed at all, while the database would be largely under-taxed by a bit tax. (2) No such tax exists for other methods of information transfer (i.e. fax), - so why would there be any on this one? (3) It is a tax on freedom of speech. It penalises the private user as much as the commercial user, with no differentiation tax-wise between them. (4) It could discourage the development and usage of the Internet resulting in economic inefficiencies. It could give rise to peculiar incentives, e.g. artificially compressing data or maintaining it in analogue form, so as to avoid paying a tax based on bits or bit count. Another economic distortion could be that companies 'build' intra-nets to avoid Internet taxes. (5) The Internet is 'environmentally friendly' in that it reduces the use of paper and other media that incur higher environmental costs. A bit tax might discourage Internet usage and thus have negative environmental consequences. (6) It may be difficult to implement, i.e. bits are difficult to count within statistically shared networks and could be hidden by encryption. (7) If not implemented on a world-wide scale it could lead to distortions in competitiveness. Otherwise, online transactions may simply be deferred to a jurisdiction where no such tax exists. Once information is priced it will become hard for individuals without an Internet connection to obtain one. In other words, by taxing the Internet we could create information 'haves' and 'have nots'.
} 
Internet in particular turn out to be not only the high cost involved but also comparative advantage, complexity, compatibility, diffusion and communication.

With respect to comparative advantage, an individual examines whether a PC with an Internet connection provides any added value. Currently, newspapers, television and radio are the most used media to collect information from. People are acquainted with these media and are satisfied with their performance and many are not willing to adapt to use the Internet. In addition, the high fees charged by Internet Service Providers (ISPs) and telecom companies are for many households a barrier to access the Internet. Table 1 shows the ranking of ISP charges in US\$PPP in 1995 and the average tariff for a one minute connection. From this table we observe that the cost of accessing the Internet are the lowest in Australia, the UK, the US, New Zealand, Canada, Finland and the Netherlands. It is not surprising that the more developed countries charge the least, since their electronic infrastructure is best developed. Surprisingly, EU countries such as Germany, Italy, Belgium and Denmark also charge high prices for an Internet connection.

Most individuals find it still too complicated to use a Personal Computer (PC). This leads us to the second factor: complexity. An individual asks himself whether he can become easily acquainted with a PC and the Internet. Unfortunately, the answer to this question is in almost all cases certainly negative. A PC is for most individuals a very complicated 'thing' to deal with, let alone the Internet which makes intensive use of an individual's computer skills. This leads us to the third factor: compatibility. Hereby we mean the extent to which the Internet fits into an individual's personal life. At this stage it seems safe to conclude that most individuals are not yet part of the IS. This is due to the high costs involved in purchasing a PC with a possible Internet connection. Figure 1 shows for Australia, Canada, Japan and the US that there is a strong positive correlation between the use of information technology and household income. For every $\$ 10.000$ increase in household income, the percentage of homes owning a computer increases by seven points. This brings us to our fourth factor, the factor of diffusion. People can only become acquainted with the Internet if they can buy a PC easily. This is currently not the case since such a computer is relatively expensive and costs over two thousand US Dollars. 
Table 1:

Ranking Internet Access Provider Charges (Dial-Up) and the Average of Peak One Minute to OECD Countries (US\$PPP)

\begin{tabular}{|c|c|c|c|c|}
\hline \multirow[t]{2}{*}{ Country } & \multicolumn{2}{|c|}{ ISP Charges in 1995} & \multicolumn{2}{|c|}{ Average of Peak One Minute } \\
\hline & 20 Hours/ Month & 30 Hours/ Month & 1991 & 1996 \\
\hline Australia & 10.45 & 16.54 & 1.23 & 1.26 \\
\hline UK & 14.67 & 14.67 & 0.89 & 0.61 \\
\hline New Zealand & 15.26 & 15.26 & 1.66 & 1.64 \\
\hline Finland & 18.85 & 18.85 & 0.99 & 0.58 \\
\hline USA & 20.64 & 20.64 & 1.34 & 1.57 \\
\hline Netherlands & 21.13 & 21.13 & 1.01 & 0.78 \\
\hline Canada & 15.96 & 27.96 & 1.37 & 0.96 \\
\hline Iceland & 24.35 & 24.35 & 1.54 & 1.11 \\
\hline Sweden & 25.10 & 25.10 & 1.06 & 0.66 \\
\hline Spain & 35.10 & 35.10 & 1.77 & 1.08 \\
\hline Norway & 35.69 & 53.07 & 0.93 & 0.49 \\
\hline Switzerland & 46.95 & 55.95 & 1.17 & 0.79 \\
\hline Portugal & 42.25 & 67.25 & 1.39 & 0.97 \\
\hline Austria & 59.32 & 59.32 & 1.23 & 1.06 \\
\hline Japan & 53.04 & 86.19 & 2.19 & 2.16 \\
\hline France & 61.37 & 91.39 & 1.14 & 0.89 \\
\hline Greece & 77.39 & 77.39 & 1.36 & 0.81 \\
\hline Mexico & 80.41 & 80.41 &.. & 2.03 \\
\hline Denmark & 67.48 & 99.64 & 0.80 & 0.62 \\
\hline Turkey & 72.97 & 117.97 & 2.74 & 0.83 \\
\hline Italy & 79.08 & 117.82 & 1.44 & 0.69 \\
\hline Belgium & 108.36 & 108.36 & 1.13 & 0.88 \\
\hline Germany & 118.06 & 162.09 & 1.00 & 0.65 \\
\hline Ireland & 153.49 & 153.49 & 1.43 & 0.84 \\
\hline Luxembourg & 154.65 & 154.65 & 1.26 & 0.80 \\
\hline
\end{tabular}

.. : Not available

Source: Worldbank (1997), OECD (1998)

Finally, we turn our attention to the factor of communication. This is perhaps the most important one, because it makes individuals aware of the greater utility associated with using the Internet. This may sound logical, but history has proven that many high-tech goods failed because of lack of communication with the potential customers - potential customers were unaware of the innovative qualities of the product - and because of a lack of skills by consumers. This is an essential point in the further growth of the Internet and gives governments an opportunity to carry out their educational programmes focussing on computer skills on the one hand and the efficient gathering of information on the other. Governments might well pay attention to ways to promote the development and availability of ICTs to advanced networks, either by means of conventional telecommunications policy measures or through other appropriate telecommunications policy 
measures. However, it is crucial to acknowledge that in the emerging IS the learning process does not take place at school or work only. Learning through consumption might be one of the most important ways to become familiar with the Internet - cf. HLEG (1997), pp. 22-25.

\section{Figure 1:}

Computer Penetration Rates by Household Income, in Australia (AUS), Canada (CAN), Japan (JPN) and the US

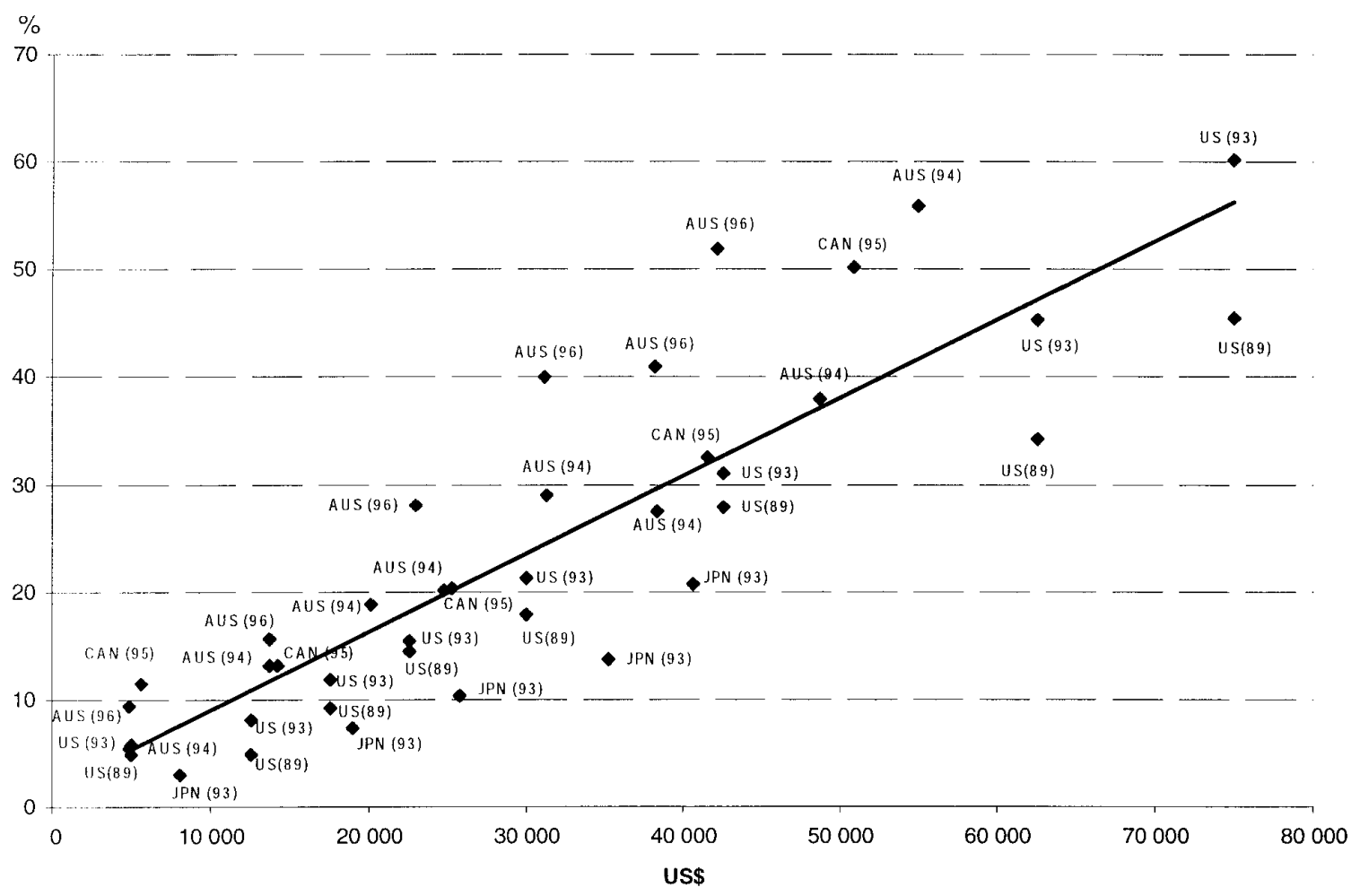

Source: OECD (1998)

Access to electronic networks can be viewed as a 'ticket' to enter the IS. This access is often viewed as essential for individuals to gain in the coming years. IT penetration rates in households reflect best how much access household members have to electronic networks. They show that the share of households equipped with computers and related goods grew significantly between the early and mid-1990s - cf. Table 2. 
Table 2:

ICT Equipment Diffusion in Several OECD Countries, 1990 and 1995

\begin{tabular}{|c|c|c|c|c|c|c|c|c|c|c|c|c|}
\hline \multirow{2}{*}{$\begin{array}{l}\% \text { of } \\
\text { households }\end{array}$} & \multicolumn{2}{|c|}{ US } & \multicolumn{2}{|c|}{ Canada } & \multicolumn{2}{|c|}{ Japan } & \multicolumn{2}{|c|}{ UK } & \multicolumn{2}{|c|}{ France } & \multicolumn{2}{|c|}{ Germany } \\
\hline & 1990 & 1995 & 1990 & 1995 & 1990 & 1995 & 1990 & 1995 & 1990 & 1995 & 1990 & 1995 \\
\hline Videotext & .. & .. & .. & .. & .. & .. & .. & .. & 16.9 & 20 & .. & .. \\
\hline Fax & .. & 6 & .. & .. & 5.5 & 10 & .. & .. & .. & 2 & .. & .. \\
\hline $\mathrm{PC}$ & 15 & 25.5 & 16.2 & 28.8 & 11.5 & 15.6 & .. & 20 & 11 & 14.3 & .. & 25 \\
\hline Modem & .. & 15 & .. & 9.8 & .. & .. & .. & 4 & .. & 1 & .. & 3 \\
\hline CD-Rom & 3.1 & 14 & .. & .. & .. & .. & .. & 7 & .. & 4.5 & .. & 11 \\
\hline Cable TV & .. & 51 & 71.4 & 73.4 & .. & 19 & .. & 4 & .. & 7 & .. & 42 \\
\hline Satellite & .. & .. & .. & .. & .. & .. & .. & 12.4 & .. & .. & .. & 17.5 \\
\hline
\end{tabular}

..: Not available

Source: OECD (1997)

If we elaborate on the rapid evolution and growth of the Internet we find the following results. Table 3 shows the number of hosts in the world. From this table we observe that by approximation the number of hosts doubles every year, except for the second half of 1997.

Table 3:

Number of Hosts in the World, 1993-1997

\begin{tabular}{|c|c|c|c|c|c|c|c|}
\hline & $01 / 01 / 93$ & 01/01/94 & $01 / 01 / 95$ & $01 / 01 / 96$ & 01/01/97 & 01/07/97 & CAGR \\
\hline USA & 942.693 & 1.475 .422 & 3.178 .266 & 6.053 .402 & 10.695 .092 & 12.849 .392 & 0.8353 \\
\hline Europe & 303.828 & 587.135 & 1.106 .077 & 2.284 .750 & 3.921 .946 & 4.840 .248 & 0.8955 \\
\hline Other & 66.479 & 66.479 & 154.443 & 567.657 & 1.528 .962 & 1.850 .360 & 1.1899 \\
\hline Total & 1.313 .000 & 2.129 .036 & 4.438 .786 & 8.905 .809 & 16.460 .000 & 19.540 .000 & 0.8817 \\
\hline
\end{tabular}

Source: Ter Weel (1997)

The fall of the growth rate of the number of Internet host is presumably due to increased congestion. Some of the high growth in users and demand for bandwidth-consuming applications is due to the pricing structure for Internet services. Local telephone calls to connect to ISPs in Europe are not free, unlike in North America, where callers are allowed to make an unlimited amount of local calls under their basic service costs. ${ }^{6}$ The lack of clear price signals, combined

\footnotetext{
${ }^{6}$ The cost of local calls is likely to rise in some countries, as former telecom monopolies rebalance their rates in preparation for the opening of all services to competition in January 1998. The reason being that they remain monopolists in regional telecom provision. On the European level former government owned telecom enterprises are forced to compete.
} 
with a very fragmented industry, creates a situation where there is little coordination and where users or ISPs do not suffer the consequences of their actions. This situation recalls the 'tragedy of the commons' associated with most public goods: as the price is low, users have no incentive to economise on its use, and they therefore engage in uneconomical activities. ${ }^{7}$ The externalities imposed on other users come in the form of delays or lost packets. Aside from hardware and access costs, there are several infrastructure issues that at present are hindering the further diffusion of the Internet throughout Europe. The development of broadband networks across Europe has been slow, and European leased-line prices remain anywhere from two to ten times higher than equivalent prices in the US. It is likely that these constraints dampen the growth of and access to the Internet.

Hence, the only major limiting factor in sight to curtail growth of the Internet and commercial websites is whether the infrastructure development can keep up. Table 4 shows the deployment of fibre-optic cable throughout the OECD in the early 1990s. Competitive pressures among web developers and storage providers promise to keep the price of entry low. Cost cutting and competitive pressures among marketeers continue to push more toward electronic marketing. Hence, the further evolution of the IS can be stimulated by the development and provision of a decent infrastructural framework and competition among all agents in the electronic commerce market, e.g. service providers. This development might lead to a radical change in the way consumers provide themselves with products. Consumers can travel all over the world in the virtual environment of the Internet and buy products everywhere. The implications of this changing attitude have strong effects on government policies. In the next section we discuss the effects of this rapidly expanding process for the tax base.

${ }^{7}$ The same holds for roads, water and air, where the price fails to reflect the costs imposed on others. 
Table 4:

Deployment of Fibre Optic Cable in the OECD Area

\begin{tabular}{|c|c|c|c|c|}
\hline Country & 1993 & 1995 & CAGR (\%) & Measure \\
\hline Australia & .. & & .. & .. \\
\hline Austria & 45.298 & 92.320 & 42.8 & Fibre km \\
\hline Belgium & 4.6550 & .. & .. & .. \\
\hline Canada & 3.696 .775 & .. & $6.9^{*}$ & .. \\
\hline Czech Republic & 1.408 & 90.336 & 701.0 & Fibre km \\
\hline Denmark & 9.300 & .. & $10.8^{*}$ & $\mathrm{Km}$ \\
\hline Finland & 164.024 & 425.955 & 61.1 & Fibre km \\
\hline France & 34.000 & .. & .. & .. \\
\hline Germany & 68.400 & 86.000 & 12.1 & .. \\
\hline Greece & 2.745 & 7.025 & 60.0 & Cable km \\
\hline Hungary & .. & .. & .. & .. \\
\hline Iceland & 156 & 315 & 42.1 & $\mathrm{Km}$ \\
\hline Ireland & 8.600 & 11.200 & 14.1 & Fibre km \\
\hline Italy & 1.333 .000 & 1.964 .000 & 21.4 & Fibre km \\
\hline Japan & 168.300 & .. & $26.3^{*}$ & $\mathrm{Km}$ \\
\hline Luxembourg & .. & .. & .. & .. \\
\hline Mexico & 8.701 & 21.610 & 57.6 & .. \\
\hline Netherlands & 12.000 & .. & .. & .. \\
\hline New Zealand & .. & .. & .. & .. \\
\hline Norway & 11.400 & 13.800 & 10.0 & Cable km \\
\hline Portugal & 15.280 & 134.128 & 196.3 & $\mathrm{Km}$ \\
\hline Spain & 24.857 & 36.041 & 20.4 & .. \\
\hline Sweden & 25.000 & .. & .. & .. \\
\hline Switzerland & 214.051 & .. & .. & .. \\
\hline Turkey & 20.700 & 28.300 & 16.9 & $\mathrm{Km}$ \\
\hline United Kingdom & 2.300 .000 & 2.800 .000 & 10.3 & $\mathrm{Km}$ \\
\hline United States & 7.545 .539 & 10.714 .811 & 19.2 & Fibre miles \\
\hline
\end{tabular}

..: Not available

*CAGR 1993-1994

Source: OECD (1997) 


\section{The need for a new tax system ${ }^{8}$}

\section{VAT problems}

Globalization of information and communication is accelerated by the growth of electronic commerce because borders between countries are eliminated. This development makes it extremely difficult to trace and therefore tax business transactions. Globalization also affects consumer choices. On the one hand, physical country borders no longer determine the mobility of individuals. On the other hand, the Internet boosts virtual mobility and globalization. Individuals surf the Internet from one country to another and act like rational agents looking for the best price-quality ratio while taking into account shipping costs. Table 5 gives an indication of the rapid evolution of the IS. Total sales and the growth of electronic commerce is approximated by several companies. Although the results differ widely across the various estimates, the overall picture shows a dramatic increase in electronic commerce.

Table 5:

Comparison of Various Total Electronic Commerce Estimates (US\$ millions)

\begin{tabular}{lrr}
\hline & $\mathbf{1 9 9 5 - 1 9 9 7}$ & $\mathbf{2 0 0 0 - 2 0 0 2}$ \\
\hline IDC & 1.000 & 117.000 \\
INPUT & 70 & 165.000 \\
VeriFone & 350 & 65.000 \\
ActivMedia & 24.400 & 1.522 .000 \\
Data Analysis & 2.800 & 217.000 \\
Yankee & 850 & 144.000 \\
E-Land & 450 & 10.000 \\
EITO & 475 & 262.000 \\
AEA/AU & 200 & 45.000 \\
Hambrecht and Quest & 1.170 & 23.200 \\
Forrester & 8.000 & 327.000 \\
Morgan Stanley & 600 & 375.000 \\
Soete and Ter Weel (1998a) EU & 46.5 &.. \\
\hline Median Value & $\mathbf{7 2 5}$ & $\mathbf{1 5 4 . 5 0 0}$ \\
\hline
\end{tabular}

Source: OECD (1998)

In the EU a Value Added Tax (VAT) is the most common consumption tax, while the US uses a system of sales taxes. In both the EU and the US, excise duties are levied on some goods such

\footnotetext{
${ }^{8}$ This section draws heavily on Soete and Ter Weel (1998a) and (1998b).
} 
as petrol, alcoholic drinks and cigarettes. The system of VAT works fairly well in the EU because it uses intermediaries and it is incentive compatible. Intermediaries are involved in the entire production process: from raw materials to the final product. These intermediaries are quite willing to participate in the VAT system and to cooperate with tax authorities because they charge the VAT to the next intermediary in the production process and, in the end, to the final consumer. In addition, they are reimbursed by the tax authorities for the VAT they pay to an upper chain intermediary. As such, an intermediary only pays VAT on the value he adds to the product. Thus, the eventual burden is on the final consumer. In an international setting a customs officer acts as the intermediary and hence taxes the incoming product at the border of the particular country.

Electronic commerce threatens EU VAT revenues for two reasons. For one, electronic commerce removes the intermediary from the production and distribution chain. A consumer can linea recta contact the producer of the good he wants to purchase. This leads to a fall in VAT revenues because most of the intermediaries have disappeared. The second reason why electronic commerce threatens VAT revenues is the fact that VAT rates in the EU are both as such very different and divert on specific products.: VAT rates range from over $20 \%$ in Sweden, Belgium and France to $15 \%$ in Germany. These large differences influence consumer behaviour in the EU. Moreover, some countries exempt particular goods from VAT, e.g. in the UK VAT on books and newspapers is zero. In general, we observe that due to increasing 'consumer mobility' countries with high VAT rates may suffer from the increasing use of electronic commerce. Their VAT revenues will fall, while countries with low rates of VAT will observe larger revenues. In short, globalization and economic integration place forward the condition for further integration and, more importantly, harmonisation of VAT rates.

To further illustrate the above tax problems, we make a distinction between goods flowing inside the EU and goods coming in from outside Europe, i.e. intra EU trade and extra EU trade. Goods coming in from outside Europe (extra EU trade) are handled by a customs officer. His role is of crucial importance: goods flowing into the EU are taxed according to the tax law of the country of destination. Thus, if a leather coat is purchased online in the US by a Swedish citizen, the customs officer at the Swedish border levies $25 \%$ VAT on the coat. Tax offices like Inland 
Revenue claim that UK customs officers trace all packages crossing the UK borders. This may be true but seems unlikely due to the high volume of goods entering the UK and the impractability of checking each one. Thus, it seems likely that many goods, such as compact discs (CDs), are entering the UK from e.g. the US without VAT being levied.

Can the custom officers be the intermediary in the age of electronic commerce? For tangible goods this is to a certain extent possible. 'Higher-valued' goods are registered when entering the EU, while other goods with lower values can flow freely amongst EU countries. With respect to services, it is very difficult, if not impossible, to trace their flow and hence levy taxes. With services, the only opportunity to levy a tax is to trace where the final user of the service resides. For this, voluntarily disclosure by end users is required. If producers are the end users of services, then this does not pose a problem since producers will be willing to disclose the services they receive because they can pass on the VAT charges. If the final user is an individual consumer, VAT revenues will fall as they try and avoid the payment of taxes.

Another option possible to obtain the foregone tax revenues on services is to shift the responsibility of disclosure to the producer of the service. In this case, the producer charges VAT directly, by increasing the price of the service by the relevant VAT rate. From a legal perspective this is no problem for producers residing in the EU because they can shift the tax burden. Producers residing in the US, however, run into problems. With the US sales tax system it is impossible to shift the tax burden. Thus, a US citizen does not pay a sales tax on services because if the government announces a sales tax on services this will worsen the competitive position of US firms. In other words, it would give US firms a comparative disadvantage. It is therefore not surprising that IBM has proposed a duty free Internet, stating that: "At a time when the U.S. Treasury and the White House have taken the more prudent route of advocating no new taxes on commercial Internet activities and are encouraging policies designed to foster its rapid expansion and development, proponents of the "bit tax" have stepped to the fore as the only group to be going in the complete opposite direction. A number of U.S. state and local movements towards taxation have reversed position, some due to pressure from the business and user community (i.e., Tacoma, Washington), others as a consequence of further study (i.e., Florida). Still others have taken the positive approach of seeking to foster Internet related activities in their 
jurisdictions (New York) by adopting Internet friendly tax laws and regulations, and others have adopted resolutions advocating support of the Clinton Administration's view (Georgia)."

The argument used by the Clinton administration is basically that it is too difficult to trace and localise the Internet user. If a sales tax is levied on US services, they would become much less attractive to foreign consumers because they are simply too expensive. The effect of a duty free Internet is advantageous to US firms relative to EU firms because EU firms still face the VAT system while the goods and services of US firms are entirely tax free. Recently, however the state of California proposed a kind of taxation on the Internet to both raise its tax revenues and to profit from the rapid evolution of Silicon Valley in the direction of electronic commerce.

So far we have discussed how tax revenues will suffer from the increasing use of electronic commerce. In the next section we discuss and evaluate different methods to prevent the tax base from further erosion in the IS.

\section{Sand in the wheels of the Internet}

Taxing electronic commerce - and in particular a bit tax - is a very controversial and hotly debated issue on the agenda of both large computer manufacturers (e.g. IBM), government agencies (e.g. the European Commission ${ }^{10}$ ) and scientists. ${ }^{11}$ Those opposing a tax on electronic commerce argue that it is "a tax on the IS" and runs the risk of slowing down the IS's evolution. However, in our view, the only way to appropriately dismiss such a tax is to do so on the basis of research - i.e. through macro econometric methods or models. Cordell (1997) argues that a tax on gasoline did not slow down the development of the automobile industry. We have to consider such statements with a certain amount of caution, because the implicit assumption is an inelastic

${ }^{9}$ IBM's response to the bit tax proposal is available on the MERIT Homepage.

${ }^{10}$ The European Commission also opposes a tax on electronic commerce. First and foremost they argue that such a tax constitutes a radical departure from value based taxation and as such would lead to a substantial distortion of production and consumption decisions and to inefficiency. Similar to IBM's argument, the Commission states that the tax is not practicable in terms of measurement and implementation, that it is incentive incompatible and would encourage avoidance. Finally, the Commission argues that a tax on electronic commerce would severely distort consumption choices on low priced or flat rate priced purchases.

${ }^{11}$ For other arguments against the taxation of electronic commerce see, e.g., Beck and Prinz (1997), Blum (1996), Du Bois (1996), Gleckman (1996) and Schneideran (1997). 
demand for cars. Whether the demand for accessing the Internet and more importantly the demand for using the Internet is inelastic remains an open question. ${ }^{12}$ In this section we introduce three proposals to fight tax erosion. In order to build up a comprehensive analysis of these proposals we illustrate a business model to show the opportunities for taxation. Figure 2 shows the basic business model for the Internet with all key players involved. These players are Network Providers (NPs), ISPs, Users, Web site Internet Shop, Payment Providers (PPs) and Software Architects (SAs).

We can identify the following six flows of money and services:

1 The User or potential Internet Shop customer pays a fee to the ISP who supplies an Internet Connection. This gives the user access to various Internet services such as WWW, e-mail etc.

2 The User visits a Web Site or Internet Shop and decides to purchase goods and/or services. To pay for items, the user obtains a payment system from a financial institution the PP (bank). The PPs also provide various services related to the system.

3 The Web Site Internet Shop purchases a permanent Internet connection or space on the ISP's computers from the ISP.

4 To provide the User with access to the Internet, the ISP purchases a set amount of bandwidth from a NP.

\footnotetext{
${ }^{12}$ On the other hand, tax revenues could be used to improve Internet access and usage. Taxes on car usage are used to maintain and build roads. In a similar fashion, electronic commerce taxes can be used to improve access and increase bandwidth. Particularly, in the EU, the improvement of the Internet is highly preferable. Critics of the fair distribution of taxes might argue that not all car taxes are used to maintain and improve roads. By the same token, they argue that taxes on electronic commerce just enter the large tax container and are not used to improve the use of and access to the Internet. This neglects the fact that governments undoubtedly play an essential role in safeguarding competition in the IS and in regulating the market to give every single inhabitant the opportunity to enter the IS. In addition, if we face an eroding tax base, governments have to search for other means to guarantee their revenues. As such, a tax on electronic commerce could turn out to be a useful tool in redistributing income and giving people a ticket to enter a new age. In addition, such a tax can provide the economy with extra needed bandwidth and the development of the Internet.
} 
5 SAs supply the Internet Shop with the software required to enable connection to an ISP and to allow customers to browse the shop.

6 If customers buy their products with a e.g. credit card, there is a revenue flow from the PP to the Internet Shop and a revenue flow from the Internet Shop to the PP to deal with commission cost.

Figure 2:

An Internet Business Model

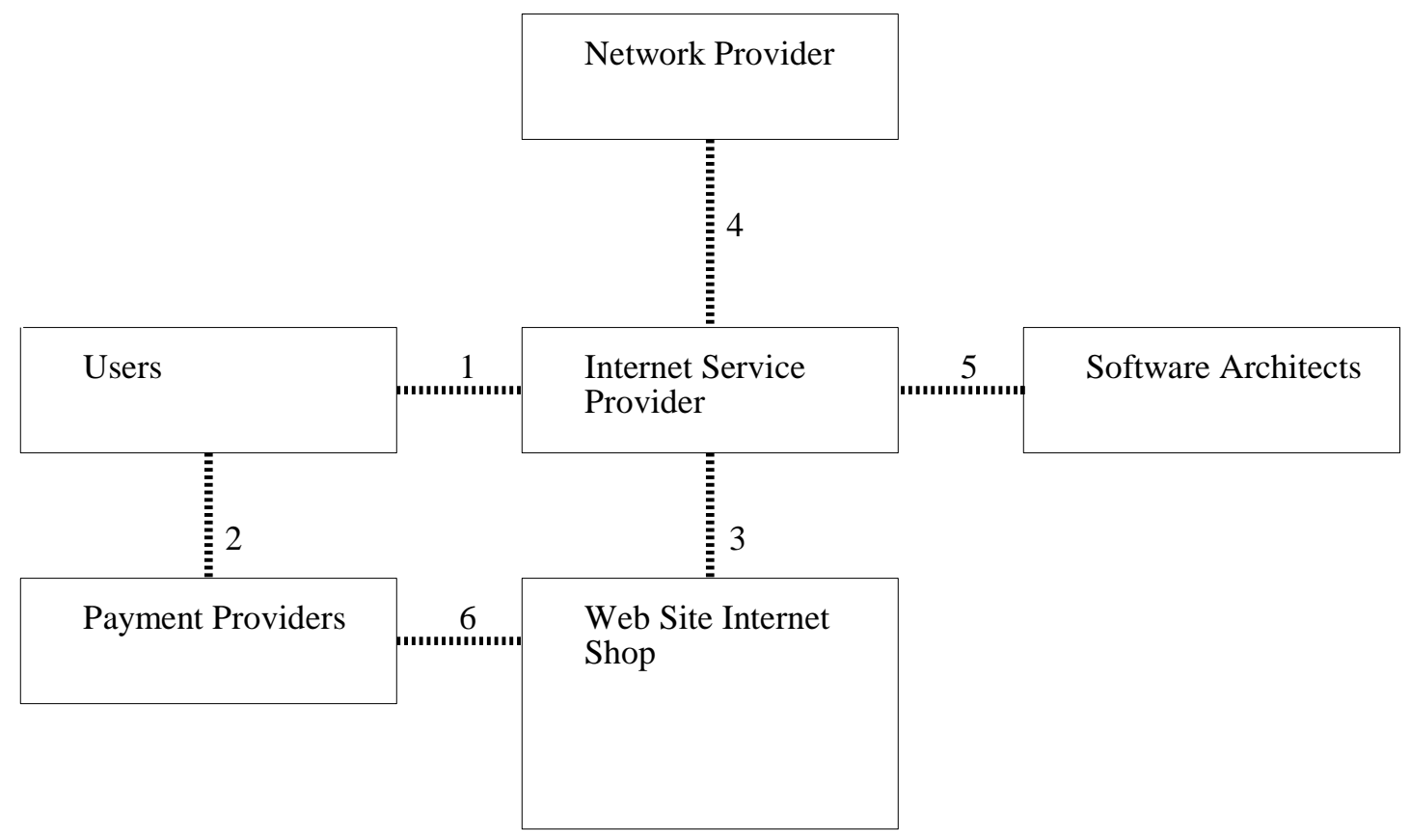

The first proposal is for the ISP to become the new tax intermediary. The Internet user or potential Internet customer, pays a fee to the ISP who supplies an Internet connection. This gives the user access to various Internet services such as the Web, e-mail etc. Since ISPs know the identity of the user, they could take the responsibility of keeping track of all financial transactions a particular user makes. This is already feasible from a technical point of view: ISPs can become the new intermediaries because they can perform identity checks on new commercial users and can account for Internet Protocol numbers (IP numbers). To be able to account for IP numbers 
they need NPs. NPs are useful and necessary in two ways. First, telecommunication bandwidth is in one sense a distribution chain and large bandwidth use is an indicator of commercial activity. Second, as distributors of IP numbers they can ensure proper accountability for IP numbers they issue. Once the user is identified the ISP can keep track of all transactions this particular user makes. All these transactions can be put on a specified bill the user receives every month. Once this happens it is very easy to levy VAT on the products the individual has purchased; it is similar to the telephone invoices received each month. There is one problem with this system however. It is currently not possible to trace IP numbers because they are assigned randomly. In the near future it is possible that every single subscriber to an ISP will receive a personal IP number, similar to the case of credit card numbers.

An advantage of this proposal is that the VAT system remains unchanged and unchallenged. However, a disadvantage of imposing VAT on the Internet use is the increasing cost of using the Internet. These higher cost could lead to a slow down of the growth of the Internet, or even to an absolute decrease in the number of users. This can have negative effects on the further evolution of the Internet in particular and the IS in general. The exact effects of the levying of VAT on Internet transactions are unknown, but are currently being investigated - cf. Meijers (1997). In addition, the previous section of this paper maps all features of the Internet market.

The second option is to appoint the financial community as intermediary in Cyberworld. However, until now financial institutions were never pushed into the role of authority and they do not trample to enter this role of control. Two options are available that allow the financial community to act as tax intermediary. For one, using electronic money (e-cash) for all electronic commerce transactions would allow VAT to be charged on the e-cash and incorporated in the price of this new form of money e.g., one unit of e-cash incorporates a certain percentage of VAT. Two, credit card companies can levy VAT on all transactions their customers make on the Internet. PPs can introduce e-cash for all electronic commerce transactions and in this way monitor all transactions individuals make on the Internet. PPs can simply monitor all transactions their customers make on the Internet and levy VAT on the final bill.

A bottle neck with having financial institutions act as the intermediary is that in order to levy 
VAT on e-cash or a credit card transaction both the financial institution - the bank or the credit card company - and the customer have to reside in the same country. This is not always the case. This problem can be easily solved, however, because a credit card needs to be fed from the customer's home country. If we are able to trace this feeding we can tax at the source. This taxing at the initial source is the general reasoning behind the idea Tobin (1978) launched for raising an international uniform tax on all spot conversions of one currency into another, as we have noted in section 2. The implementation problem is characterized by the public goods nature of the tax. This implies two things: unilateral action is totally ineffective and concerted action will be confronted with the free-rider problem.

Upon closer examination of Figure 2 we observe that Web Site Internet Shops can also play a role in the collection of VAT. Since tax authorities have full access to those parts of a website containing transaction logs and financial data, it would be quite feasible to implement payment of tax directly from the business website to the tax-authorities website. Furthermore, in developing internationally accepted identification and authentication standards applicable to financial transactions, SAs can build a system, embedded in popular web browsers such as Netscape Navigator or Microsoft Explorer, to enable reporting of financial transactions - cf. ATO (1997) for a discussion.

The final option we consider is the method of last resort: sand in the wheels of the Internet or the bit tax. The bit tax is basically a tax on the volume of the transaction (the number of bits sent) rather than the value of the transaction. The bit tax is equal to an excise duty: a taxation on the use of the information superhighway's bandwidth. The original bit tax proposal was made by Cordell and Ide (1994) in a Club of Rome report. They argue that the existing tax structure on value would no longer make sense in the information society and propose a bit tax as a replacement for VAT on information technology goods and services, rather than as an additional tax. Furthermore, they argue that VAT is heavily based on the material inputs that occur at different stages of the manufacturing process and is, as such, not well-suited to 'intangible' services. In the case of information and communication services it is very difficult to talk in any real or meaningful way about a tax on value added. A telephone call is currently priced and taxed in relation to distance and time and has no relationship to the possible value of the 
communication. Therefore, we need the bit rather than the second as the fundamental unit of measure to minimise the leakage and erosion in the contemporary tax system. SPRINT Corporation is currently investigating whether they can customize on free lines by using bits instead of time as measurement unit. Cordell (1997) argues that it is an easily administrated tax on each digital bit of information. Furthermore he recognizes: "[w]hether the digital bit is part of a foreign exchange transaction, a business teleconference, an Internet e-mail of file transfer, electronic check clearance or an ATM transaction, each bit is a physical manifestation of the new economy at work." (p. 9)

Taxation on that basis might save small-scale users money while increasing the tax burden on large-scale users. The bit tax would be paid by individual users and levied by their online ISPs. In addition, the bit tax should be a generic tax exerted on all electronic traffic and be introduced on a world-wide basis to avoid distortions. The common rate of taxation is set by Cordell randomly at 0.000001 cent per bit. A major advantage of the bit tax, although it taxes volume instead of value, is that the collection will cause less distortions to the economy than most other direct or indirect taxes. Collected by ISPs or NPs the revenues will flow directly to the national tax authorities of the respective country, omitting the problem of residence.

Although the exact implementation of such a tax is not yet clear, the general idea of a tax on information from the point of view of an eroding tax base and the changing society is certainly worth considering. Furthermore, the tax revenues could be directed towards improving access to the Internet, educating individuals to become acquainted with the Internet and providing additional needed bandwidth. 


\section{Concluding Remarks}

The idea of taxing electronic commerce has been met with a barrage of negative reactions on the side of policy makers, industry and consumers. Nevertheless, over the past year, the issue of an eroding tax base linked to the development of electronic networks replacing physical ones has grown in importance. Although the exact implementation is very hard to accomplish, the general idea of a tax on information from the point of view of an eroding tax base and the changing society, certainly is worthwhile considering. Furthermore, the tax revenues can be moved directly towards improving access to the Internet, educating individuals to become acquainted with the Internet and providing the additional needed bandwidth.

Building a business model gives us the advantage of the feasibility of the implementation of a tax on electronic commerce. We have seen that the implementation problems can be overcome by either enforce ISPs or PPs as tax collectors. ISPs can monitor all transactions their customers make. Hence, they can put VAT on these transactions. ISP customers receive at the end of the month not only the bill for access but also a bill including VAT regarding the transactions they made. PPs can by either e-cash or credit card numbers trace the transactions of Internet users. Ecash can be taxed ex ante if it is not possible to locate the user, otherwise users receive an e-cash bill including VAT at the end of each month. Furthermore, a credit card company can record all transactions and announce VAT on it. Finally, as a method of last resort, the bit tax can be implemented. Now, ISPs keep record of all bits flowing over the Internet.

Next to this, we have to improve access to the information society by stimulating people and making people aware of the fact that ones they miss entrance to the IS they fall behind forever. This awareness can be created in providing proper training and education programmes. In addition, the cost of entering the information society have to fall dramatically in order to guarantee equal chances for all citizens. On this view of things, a tax on electronic commerce can turn out to be a useful tool in redistributing income and giving people a ticket to enter a new age. In addition, such a tax can provide the economy with extra needed bandwidth and the development of a comprehensive Internet. 


\section{References}

Australian Tax Office (1997), Tax and the Internet, Discussion Report of the ATO Electronic Commerce Project.

Beck, H. and A. Prinz (1997), Should All the World be Taxed? Taxation and the Internet, Intereconomics, March/April.

Blum, D.C. (1996), State and Local Taxing Authorities: Taking More than Their Fair Share of the Electronic Information Age, The John Marshall Journal of Computer \& Information Law, no. 3, pp. 493-522.

du Bois, M. (1996), Down on the Levy: Next Time Your PC Crashes, Take it as Tax Deduction, Convergence, summer issue.

Cordell, A.J. (1997), International Tax Program and the Society for Law and Tax Policy, Paper presented at the 1997 Spring Symposium, April 5, Harvard Law School.

Cordell, A.J. and J. Ide (1994), The New Wealth of Nations, Taxing Cyberspace, Between the Lines Publishers.

Eichengreen, B., J. Tobin and C. Wyplosz (1995), Two Cases for Sand in the Wheels of International Finance, The Economic Journal, vol. 105, no. 1, pp. 162-172.

Frankel, J.A. (1996), How Well Do Foreign Exchange Markets Function: Might a Tobin Tax Help?, NBER Working Paper no. 5422.

Freeman, C. and L.L.G. Soete, Work for All or Mass Unemployment?: Computerised Technical Change into the Twenty-First Century, London, Pinter.

Ganguly, R. (1997), Taxation of Cyberspace Transactions: Working Towards Solutions, Paper presented at the 1997 Spring Symposium, April 5, Harvard Law School.

Gleckman, H. (1996), The Tax Cometh to Cyberspace. Governments Want a Piece of Pie. But What Will Work?, Business Week, 9 December 1996, pp. 44-45.

High Level Expert Group (1997), Building the European Information Society for Us All, Final Policy Report of the High-Level Expert Group, Employment and Social Affairs, European Commission.

van Liederkerke, L. (1997), The Tobin Tax: A Tool for Monetary Reform and Distributive Justice, Centrum voor Ethiek, UFSIA.

Meijers, H.H.M. (1997), Information Society: New Ways of Work, Final Report to the Statistical Office of the European Communities, MERIT, Maastricht. 
OECD (1997), IT Outlook, OECD Paris.

OECD (1998), The Economic and Social Impact of Electronic Commerce, OECD, Paris.

Schneideran, A. (1997), Three Myths about Government, Markets, and The Net: A Special Report on the Clinton Administration's Plans for Global Electronic Commerce, ENODE, vol. 2, no. 4, July.

Soete, L. and B. Ter Weel (1998a), Cybertax, Futures, vol. 30, no. 9, forthcoming November.

Soete, L. and B. ter Weel (1998b), Sand in the Wheels of the Internet, MERIT mimeo.

Soete, L. and B. Ter Weel (1998c), Toename Handel via Internet Vraagt om Radicale Herziening Belastingstelsels, De Volkskrant, 28 September, p.7.

Stahl, D.O. (1997), A Critical Survey of Internet Pricing Proposals, in: Dumort, A. and J. Dryden (eds.) (1997), The Economics of the Information Society, EUR 16676 EN, European Commission/ OECD, Brussels/ Paris, pp. 142-154.

Ter Weel, B. (1997), Cybertax, MERIT Research Memorandum 97-019, MERIT, Maastricht University

Tobin, J. (1978), A Proposal for International Monetary Reform, Eastern Economic Journal, vol. 4, pp. 153-159.

Worldbank (1997), World Development Indicators, Worldbank, Washington/ New York. 